\title{
Post-publication peer review: another sort of quality control of the scientific record in biomedicine
}

\author{
Mirna Martínez-Saucedo, ${ }^{1}$ Samara Téllez-Camacho, ${ }^{2}$ Guillermo Aquino-Jarquín, ${ }^{1}$ Rocío Sánchez-Urbina ${ }^{3}$ \\ and Javier T. Granados-Riverón ${ }^{1 *}$ \\ 'Laboratory of Genomics, Genetics and Bioinformatics Research, Hospital Infantil de México "Federico Gómez", Secretaría de Salud, Mexico City; \\ ${ }^{2}$ University Center of Biological and Agriculture \& Livestock Sciences, Universidad de Guadalajara, Jalisco; ${ }^{3}$ Laboratory of Developmental Biology \\ and Experimental Teratogenesis Research, Hospital Infantil de México "Federico Gómez", Secretaría de Salud, Mexico City. Mexico
}

\begin{abstract}
Traditional peer review is undergoing increasing questioning, given the increase in scientific fraud detected and the replication crisis biomedical research is currently going through. Researchers, academic institutions, and research funding agencies actively promote scientific record analysis, and multiple tools have been developed to achieve this. Different biomedical journals were founded with post-publication peer review as a feature, and there are several digital platforms that make this process possible. In addition, an increasing number biomedical journals allow commenting on articles published on their websites, which is also possible in preprint repositories. Moreover, publishing houses and researchers are largely using social networks for the dissemination and discussion of articles, which sometimes culminates in refutations and retractions.
\end{abstract}

KEY WORDS: Post-publication peer review. Social networks. Biomedicine.

\section{La revisión por pares pospublicación: otro control de calidad del registro científico en biomedicina}

\section{Resumen}

La revisión por pares tradicional atraviesa por crecientes cuestionamientos, dado el aumento en el fraude científico detectado y la crisis de replicación que recientemente se ha presentado en la investigación biomédica. Investigadores, instituciones académicas y agencias de financiamiento activamente promueven el análisis del registro científico y se han desarrollado múltiples herramientas para lograrlo. Diferentes revistas biomédicas se fundaron con la revisión por pares pospublicación como característica; existen varias plataformas digitales que hacen posible este proceso. Asimismo, cada vez hay más revistas biomédicas que permiten comentar artículos publicados en sus sitios web, lo cual también es posible en repositorios de preimpresiones. Sumado a esto, las casas editoriales y los investigadores están usando ampliamente las redes sociales para la difusión y discusión de artículos, lo cual a veces culmina en refutaciones y retracciones.

PALABRAS CLAVE: Revisión por pares pospublicación. Redes sociales. Biomedicina.

\footnotetext{
Correspondence:

*Javier T. Granados-Riverón

E-mail: JavierTGranados@ himfg.edu.mx

Gac Med Mex. 2020;156:523-526

Contents available at PubMed

www.gacetamedicademexico.com

0016-3813/@ 2020 Academia Nacional de Medicina de México, A.C.. Published by Permanyer. This is an open access article under the CC BY-NC-ND license (http://creativecommons.org/licenses/by-nc-nd/4.0/).

Date of reception: $21-02-2020$

Date of acceptance: 10-03-2020

DOI: 10.24875/GMM.M21000453
} 


\section{Introduction}

Peer review is the process that allows the researchers' community to ensure the quality of scientific records. In a previous paper, ${ }^{1}$ we discussed the mechanisms and the most important problems currently faced by the traditional peer review process. In general, a scenario of high volume and little incentives for reviewers has determined an increase in the materials required to publish an article, as well as a substantial increase in the time invested to complete the evaluation processes, which, altogether, has increased the potential for scientific fraud. ${ }^{1}$

Once published, an article becomes part of the scientific record, unless it is withdrawn by the authors or the editor of the journal it was published in. As a reaction to the problems inherent to peer review, in recent years we have witnessed a diversification of the means that enable evaluation of an article after its publication, which has been called post-publication peer review.

In view of the so-called "replication crisis", ${ }^{2}$ which has led to suggest that most part of published science is false, ${ }^{3}$ and of the progressive reduction of available economic resources, the need for scrutiny of the scientific record has become more evident than ever for academics, institutions and research-funding agencies.

Traditionally, one of the few means for evaluation of an article after its publication were the letters to the editor. In this type of communications, one or several authors can express their reservations regarding the rigor, methodological value or validity of the conclusions presented in an article. However, this process is usually slow and often encounters varying degrees of resistance from biomedical journals' editors, since it can potentially evince flaws in the scientific review and editing process.

In the following sections, we describe the efforts being made at different fronts to make the already existing scientific record refining process more expedite and efficient (Table 1).

\section{Journals and platforms with post-publication peer review}

As a result of the above-mentioned problems, which are inherent to classic publishing procedures, different entities have created journals that, initially, operated under the post-publication peer review modality. F1000Research, ${ }^{4}$ and the Copernicus, ${ }^{5}$ MedEdPublish ${ }^{6}$ and $\mathrm{Sci}^{7}$ journals are the most emblematic examples of this modality and that, in addition, promote the concept of open peer review, where all information exchange, questionings and their replies are made public as they are generated, along with all versions submitted by the authors throughout the process.

The increasing volume of scientific literature that is published every day makes it very difficult for a reader interested in a specific subject keeping abreast of all advances in his/her field. This motivated the creation of a platform dedicated to post-publication peer review, F1000Prime. ${ }^{8}$ The content of this resource is contributed by panels of recognized researchers who collaborate by invitation, and who regularly submit recommendations of articles that, in their opinion, are of significance for their field of study and deserve special attention. On the other hand, Pubpeer ${ }^{9}$ is another resource that allows discussion and analysis, even anonymously, of published works. There are examples of scientific fraud detection that led to retractions of articles thanks to this resource. ${ }^{10}$ Furthermore, certain platforms, the primary purpose of which is other, allow post-publication peer review, among them Researchgate, ${ }^{11}$ a social network that is widely used by researchers, where users can comment on articles other authors post on their personal profiles. Publons ${ }^{12}$ is a platform designed to build a researcher's profile, where scientific production is incorporated in terms of articles, patents, as well as post-publication reviews of literature generated by other researchers. Finally, the Winnower ${ }^{13}$ RIO, PubPub and ScienceOpen ${ }^{14}$ are solutions for all stages of editorial process, which, naturally, include functionalities for post-publication peer review.

\section{Comments as footnotes of online articles and preprint repositories}

Currently, the vast majority of scientific journals maintain Internet pages where consulting published issues tables of contents is possible, in addition to the title, abstract and, sometimes free of charge or upon payment, the content of each article. At the bottom of each article, sections where users can leave comments on the publication are increasingly being included. Generally, comments can be written after logging in to the journal or its publishing house's system, or on Twitter, Facebook or other social networks. Depending on the journal, these comments are immediately displayed, or after approval by a moderator in 
Table 1. Internet addresses of the different post-publication peer review resources referred to in this article

\begin{tabular}{l|l|l}
\hline Resource & Internet address & Description \\
\hline F1000Research & https://f1000research.com/ & Publishing platform \\
\hline Copernicus & https://publications.copernicus.org/ & Publication of journals with PPPR \\
\hline MedEdPublish & https://www.mededpublish.org/ & Electronic journal with the PPPR modality \\
\hline Sci & https://www.mdpi.com/journal/sci & Electronic journal with the PPPR modality \\
\hline F1000Prime & https://f1000.com/ & Article recommendation service \\
\hline Pubpeer & https://pubpeer.com/ & Online platform for PPPR \\
\hline Researchgate & https://www.researchgate.net/ & Professional network for scientists and researchers \\
\hline Publons & https://publons.com/ & Platform to create researcher profiles \\
\hline The Winnower & https://thewinnower.com/ & Open access online academic publishing platform that uses PPPR \\
\hline RIO & https://riojournal.com/ & Academic editorial platform \\
\hline PubPub & https://www.pubpub.org/ & Site that provides support at each step of the publishing process \\
\hline ScienceOpen & https://www.scienceopen.com/ & Open access platform that helps researchers in the publishing process \\
\hline Arxiv & https://arxiv.org/ & Free distribution service and open-access archive for academic articles \\
\hline BioR $x i v$ & https://www.biorxiv.org/ & Free online archive and distribution service for unpublished preprints \\
\hline PPPR = post-publication peer review. &
\end{tabular}

order to limit the use of offensive or inappropriate language.

In a previous communication, we analyzed the importance and implications of the preprint model in biomedicine. ${ }^{1}$ In this article, this modality also requires to be mentioned, in the sense that, in preprints repositories (i.e., Internet sites where these publications are stored and distributed) such as Arxiv or bioR $\chi$ iv, among others, a form of post-publication peer review in the form of footnotes at each preprint is promoted, similar to that described in the previous paragraph.

\section{The impact of social networks}

The great advances in telecommunications that have been experienced in recent decades have favored an explosive proliferation of different social networks. Different publishing houses have not remained on the fringes of this phenomenon and, currently, it is not unusual to find that biomedical journals manage accounts on different networks, specially on Twitter, Facebook and Instagram. This trend, a direct descendant of the content lists that are periodically sent by scientific journals via email, has greatly expedited the dissemination of new articles among potential readers. Moreover, given their extremely wide use, much of current discussion on scientific publications occurs under the shelter of social networks. Various studies find a positive correlation between tweets related to a publication and the citations it obtains. ${ }^{15-17}$

The power of social networks as means for post-publication review has been demonstrated: comments on Twitter triggered processes that culminated in refutations and retractions of articles in the prestigious journal Science. ${ }^{18}$

\section{Conclusions and final considerations}

The motivations for carrying out a post-publication peer review of an article can be varied; for example, as new technologies become available, previous findings can be interpreted in different forms: new observations are generated that discredit their methodology or results, or the inability to reproduce their experiments or results. Another motivation is the selection of articles with special relevance to advances in a specific field, highlighting it over other apparently similar works.

Thanks to the widespread and prevalent use of the Internet by biomedical researchers and consumers of the literature they generate, we are witnessing an organic diversification and growth of resources 
designed to create, disseminate and evaluate science. We can only expect that this huge variety of resources, entirely or partially dedicated to post-publication peer review, will increase in the near future; their classification and description can be confusing if the way these publications originated and how they are transformed is not considered, since, to paraphrase Theodosius Dobzhansky, nothing in biology makes sense except in the light of evolution. ${ }^{19}$

\section{Conflicts of interest}

The authors declare that they have no conflicts of interest.

\section{Funding}

The authors did not receive any sponsoring to carry out this article.

\section{Ethical disclosures}

Protection of human and animal subjects. The authors declare that no experiments were performed on humans or animals for this research.

Confidentiality of data. The authors declare that no patient data appear in this article.

Right to privacy and informed consent. The authors declare that no patient data appear in this article.

\section{References}

1. Aquino-Jarquín G, Valencia-Reyes JM, Silva-Carmona A, Granados-Riverón JT. Preimpresiones en biomedicina: ¿alternativa o complemento al modelo tradicional de publicación? Gac Med Mex. 2018;154:87-91.

2. Baker M. 1,500 scientists lift the lid on reproducibility. Nature. 2016:533:452-454

3. Ioannidis JPA. Why most published research findings are false. PLoS Med. 2005;2:e124-e124.

4. Kirkham J, Moher D. Who and why do researchers opt to publish in post-publication peer review platforms? - findings from a review and survey of F1000 Research. F1000Res. 2018;7:920.

5. Schmidt B, Ross-Hellauer T, van Edig X, Moylan EC. Ten considerations for open peer review. F1000Res. 2018:7:969.

6. MedEdPublish. Med Teach. 2015;37:794-796.

7. Rittman M, Vázquez F. Sci-An open access journal with post-publication peer review. Sci. 2019:1:1.

8. Bornmann L, Haunschild R. Do altmetrics correlate with the quality of papers? A large-scale empirical study based on F1000Prime data. PLoS One. 2018;13:e0197133-e0197133.

9. Teixeira-da Silva JA, Al-Khatib A, Dobránszki J. Fortifying the corrective nature of post-publication peer review: identifying weaknesses, use of journal clubs, and rewarding conscientious behavior. Sci Eng Ethics. 2017:23:1213-1226.

10. Koppers L, Wormer H, Ickstadt K. Towards a systematic screening tool for quality assurance and semiautomatic fraud detection for images in the life sciences. Sci Eng Ethics. 2017;23:1113-1128.

11. Meier A, Tunger D. Survey on opinions and usage patterns for the Research Gate platform. PLoS One. 2018;13:e0204945.

12. Swiontkowski M. Publons: the next step in reviewer recognition. J Bone Joint Surg Am. 2019:101:1137.

13. Tattersall A. For what it's worth-the open peer review landscape. Online Inf Rev. 2015;39:649-663.

14. Tennant JP, Dugan JM, Graziotin D, Jacques DC, Waldner F, Mietchen D, et al. A multi-disciplinary perspective on emergent and future innovations in peer review. F1000Res. 2017;6:1151.

15. Eysenbach G. Can tweets predict citations? Metrics of social impact based on Twitter and correlation with traditional metrics of scientific impact. J Med Internet Res. 2011;13:e123.

16. Shuai $X$, Pepe A, Bollen J. How the scientific community reacts to newly submitted preprints: article downloads, Twitter mentions, and citations. PLoS One. 2012;7:e47523.

17. Chiang AL, Rabinowitz LG, Alakbarli J, Chan WW. Tu1108 social media exposure is independently associated with increased citations of publications in gastroenterology. Gastroenterology. 2016;150:S845.

18. Yeo SK, Liang X, Brossard D, Rose KM, Korzekwa K, Xenos MA, et al. The case of \#arseniclife: blogs and Twitter in informal peer review. Public Underst Sci. 2017;26:937-952.

19. Dobzhansky T. Nothing in biology makes sense except in the light of evolution. Am Biol Teach. 1973;35:125-129. 